\title{
PENGARUH ORIENTASI INOVASI TERHADAP KINERJA UMKM BIDANG KULINER
}

\author{
Kevin Rynardo dan Louis Utama \\ Program Studi Manajemen Fakultas Ekonomi Universitas Tarumanagara, Jakarta \\ Kevinryn10@gmail.com \\ louisu@fe.untar.ac.id
}

\begin{abstract}
The purpose of this study was to determine whether creativity, risk taking, future orientation, openness to change, and proactivity affect MSME performance. The population in this study is SMEs in the culinary field. The sample used in this study were 60 respondents from SMEs in the culinary field in the city of Tanjungpinang. The sampling technique used is convenience sampling by distributing online questionnaires which are then processed using SmartPLS. The results of this study are: 1) Creativity affects the performance of SMEs in the culinary field in Tanjungpinang city, 2) Risk taking affects the performance of SMEs in the culinary field in Tanjungpinang city, 3) Future orientation affects the performance of SMEs in the culinary field in Tanjungpinang city, 4) Openness to Change affects the performance of SMEs in the culinary field in Tanjungpinang city, 5) Proactivity does not affect the performance of SMEs in the culinary field in Tanjungpinang city.
\end{abstract}

Keyword : Orientation innovation, Firm Perfomance, Creativity

Abstrak: Tujuan penelitian ini adalah untuk mengetahui apakah Kreativitas, Pengambilan Resiko, Orientasi Masa Depan, Keterbukaan Untuk Berubah, dan Proaktif berpengaruh terhadap Kinerja UMKM. Populasi dalam penelitian ini adalah UMKM bidang kuliner. Sampel yang digunakan pada penelitian ini yaitu 60 responden UMKM bidang kuliner di kota Tanjungpinang. Teknik pengambilan sampel yang digunakan yaitu convenience sampling dengan menyebar kuesioner secara online yang kemudian diolah menggunakan SmartPLS. Hasil dari penelitian ini yaitu : 1) Kreativitas berpengaruh terhadap Kinerja UMKM bidang kuliner di kota Tanjungpinang, 2) Pengambilan Resiko berpengaruh terhadap Kinerja UMKM bidang kuliner di kota Tanjungpinang, 3) Orientasi Masa Depan berpengaruh terhadap Kinerja UMKM bidang kuliner di kota Tanjungpinang, 4) Keterbukaan Untuk Berubah berpengaruh terhadap Kinerja UMKM bidang kuliner di kota Tanjungpinang, 5) Proaktif tidak berpengaruh terhadap Kinerja UMKM bidang kuliner di kota Tanjungpinang.

Kata Kunci : Orientasi Inovasi, Kinerja Usaha, Kreativitas

\section{LATAR BELAKANG}

Saat ini dunia sedang menghadapi pandemi Covid-19. Kasus Covid-19 pertama kali ditemukan pada tanggal 20 Desember 2019 di kota Wuhan. Penyebaran virus Corona ini sangat cepat dan sudah menyebar luas ke berbagai belahan dunia. Hal ini membuat World Health Organization secara resmi mendeklarasikan virus Corona sebagai pandemi pada tanggal 9 Maret 2020. Untuk menahan laju nya penyebaran virus Corona banyak negara yang memilih untuk melakukan lockdown.

Indonesia merupakan salah satu negara yang sedang menghadapi pandemi Covid-19. Virus ini pertama kali masuk ke Indonesia pada bulan Maret 2020 dan menular sangat cepat di Indonesia, pada tanggal 12 Maret 2021 kasus yang terkonfirmasi Covid-19 di Indonesia 
sebanyak 1.410.134 orang (Muhyiddin, 2020). Penyebaran virus Covid-19 yang sangat cepat menyebabkan masyarkat sadar terhadap kesehatan diri sendiri, sehingga masyarakat memilih untuk mengurangi kegiatan di luar rumah. Hal ini mengakibatkan adanya perubahan perilaku konsumen, daya beli masyarakat juga menjadi berkurang dikarenakan pandemi covid-19 menyebabkan banyak tenaga kerja kehilangan pendapatan. Sebagian masyarakat sangat berhatihati dalam mengatur keuangannya karena ketidakpastian kapan pandemi ini akan berakhir. Hal ini mengakibatkan pendapatan para pelaku usaha mengalami penurunan yang berdampak terhadap kinerja usaha.

Usaha Mikro, Kecil, dan Menengah (UMKM) merupakan usaha yang terkena dampak yang paling besar. Sebanyak 94,69\% UMKM mengalami penurunan penjualan dimana sektor kuliner terkena dampak paling besar. Sebanyak 72,02 persen UMKM menyatakan tidak dapat mempertahankan usahanya, hal ini dikarenakan penurunannya pendapatan yang signifikan dan sementara biaya produksi tetap (Nugroho, 2020). Untuk bisa bertahan bahkan memperoleh pendapatan maka para pelaku UMKM harus dapat berorientasi inovasi. Dengan adanya orientasi inovasi memungkinkan bisnis untuk mempelajari dan melacak kebutuhan pelanggan, untuk mengembangkan produk atau layanan baru yang sesuai dan untuk menerapkan proses internal yang meningkatkan pemahaman tentang kebutuhan pelanggan dan pengembangan produk, sehingga bisnis dapat tercapai dan mempertahankan kepemimpinan di pasar sasarannya (Ergun \& Kuscu, 2013). Dengan adanya orientasi inovasi yang diterapkan dengan baik dapat membantu perusahaan meningkatkan pendapatan penjualan, menarik pelanggan, dan pertumbuhan kinerja (Karabulut, 2015). Dimensi utama orientasi inovasi adalah sebagai berikut: kreativitas, pengambilan resiko, orientasi masa depan, keterbukaan untuk berubah dan proaktif (Werlang \& Rossetto, 2019). (Zainal, 2020)

Sentral utama dari aktivitas UMKM adalah kreativitas (Barringer \& Ireland, 2006). Dimana dengan adanya kreativitas dapat meningkatkan pendapatan. UMKM yang mengadopsi kreativitas dapat menghasilkan ide-ide baru untuk inovasi layanan dan memiliki peluang lebih besar untuk mencapai kesuksesan pasar melalui pengembangan produk dan proses baru (Giannopoulou \& Gryszkiewicz, 2014). Kreativitas berperan penting untuk menaikkan pendapatan penjualan sehingga berpengaruh terhadap kinerja usaha (Amabile T. M., 1998).

Pengambilan resiko juga penting untuk mendorong tercapainya kinerja perusahaan. Pengambilan resiko merupakan bagian penting dari bisnis, dan pertumbuhan usaha bergantung pada operasi pada tingkat resiko yang tepat. Kebanyakan orang lebih suka berada dalam titik yang aman dan nyaman dengan tidak mengambil hal yang beresiko atau lebih memilih resiko yang lebih rendah. Berbeda dengan pelaku UMKM resiko dijadikan sebagai tantangan untuk mencapai kesuksesan. Kecenderungan resiko UMKM menunjukkan kecenderungan bisnis terhadap resiko, karena ini menunjukkan tingkat resiko yang akan dikaitkan dengan tingkat kinerja bisnis yang lebih tinggi (Wiklund, 2005). Pengambilan resiko terdapat pengaruh yang signifikan terhadap kinerja usaha (Mwaura, Gathenya, \& Kihoro, 2015).

Orientasi masa depan atau sejauh mana bisnis dipandang sebagai kepedulian terhadap masa depan, mengambil pandangan jangka panjang, merencanakan ke depan, dan sebagai fokus perusahaan dalam memenuhi kebutuhan masa depan pelanggan dan menarik pelanggan baru (Hillebrand, Kemp, \& Nijssen, 2011). Peusahaan diwajibkan untuk harus motivasi, perencanaan, dan evaluasi. Motivasi ini berkaitan dengan hal-hal yang ingin dicapai oleh suatu perusahaan, perencanaan berkaitan dengan langkah-langkah pencapaian, dan evaluasi berkatian dengan keyakinan dan harapan bahwa tujuan masa depan yang telah direncanakan akan tercapai. Orientasi masa depan memberikan kepercayaan terhadap pelanggan, karena pelanggan merasa bahwa bisnis tersebut mengambil pandangan jangka panjang, berkelanjutan dan lebih mungkin ada di masa depan. Sehingga dengan adanya orientasi masa depan dapat memberikan pengaruh yang siginifikan terhadap kinerja usaha (Simpson \& Radford, 2014). 
Keterbukaan untuk berubah mengacu pada fleksibilitas atau kemampuan beradaptasi dan mencakup kesediaan untuk mendukung perubahan (Anberg \& Banas, 2000). Pada saat pandemi ini perilaku konsumen berubah, dimana konsumen menjadi takut untuk keluar rumah, sehingga mengakibatkan penurunannya penjualan. Hal ini mengakibatkan pelaku usaha untuk beradaptasi terhadap perubahan yang terjadi. Pelaku usaha bisa melakukan penjualan secara online, sehingga dapat meningkatkan penjualan. Kesiapan pelaku usaha terhadap keterbukaan untuk berubah adalah prasyarat untuk membawa perubahan terhadap kinerja usaha (Miller, Johnson, \& J.Grau, 1994)

Proaktif merupakan kemampuan untuk mengantisipasi dan memprediksi produk dan layanan masa depan dan berusaha untuk menyediakannya, bahkan ketika konsumen mungkin belum memiliki pengetahuan tentang produk atau fitur tersebut (Kallmuenzer \& Peters, 2018). Selera dan permintaan konsumen yang berubah membutuhkan proaktif yang ekstrim dalam perusahaan. Sikap proaktif ini cenderung mengarah pada tindakan yang positif. Dimana pada saat ini pelaku usaha terkena dampak dari pandemi Covid-19, sehingga pelaku usaha harus memiliki sikap proaktif ini untuk mempertahankan usahanya dan meningkatkan kinerja usahanya dalam masa pandemi ini. Sikap proaktif memberikan pengaruh yang signifikan terhadap kinerja usaha (Lumpkin \& Dess, 1996).

\section{KAJIAN TEORI}

\section{Kreativitas}

Kreativitas didefinisikan sebagai generasi ide baru dan berguna (Amabile T. , 1983). Kreativitas adalah sebuah ide atau cara berpikir dalam menciptakan sesuatu hal baru untuk memenuhi pasar atau kebutuhan masyarakat yang belum ada pada saat ini (Willison \& Rodhiah, 2021).

\section{Pengambilan Resiko}

Pengambilan Resiko didefinisikan sebagai kecenderungan perusahaan untuk mengambil risiko untuk memperoleh keuntungan (John, Litov, \& Yeung, 2008). Pengambilan Resiko didefinisikan sebagai pendorong fundamental terhadap kinerja dan pertumbuhan perusahaan (Nakano \& Nguyen, 2012).

\section{Orientasi Masa Depan}

Orientasi Masa Depan merupakan sejauh mana bisnis dipandang sebagai kepedulian terhadap masa depan, mengambil pandangan jangka panjang, dan merencanakan ke depannya (Erdem \& Swait, 1998). Orientasi Masa Depan memungkinkan perusahaan untuk mengungguli pesaing yang kurang berwawasan ke depan (Boyd, 1991).

\section{Keterbukaan Untuk Berubah}

Keterbukaan Untuk Berubah merupakan kemauan perusahaan untuk mengadopsi inovasi (Hult, Hurley, \& Knight, 2004).Keterbukaan untuk berubah adalah kemauan psikologis seseorang untuk menerima perubahan pada perusahaan atau lingkungan (Wanberg \& Banas, 2000).

\section{Proaktif}

Organisasi proaktif mencari dan memanfaatkan peluang, bereksperimen dengan perubahan, dan mengantisipasi serta bertindak sesuai kebutuhan masa depan, meskipun tidak harus dengan menjadi yang pertama (Lynn, Monroe, \& Paulson, 1996). Proaktif merupakan kemampuan untuk menciptakan kesempatan atau keahlian untuk mengenali ataupun 
mengantisipasi dan bertindak atas peluang (bahaya) ketika mereka memprioritaskan dirinya sendiri (Dita \& Soelaiman, 2021).

\section{Kinerja}

Kinerja mencakup berbagai pengertian yang berbeda, seperti : pertumbuhan, profitabilitas, pengembalian, produktivitas, efiensi dan daya saing (Colase, 2009). Kinerja merupakan pilar utama keberlangsungannya suatu usaha (Ndofor \& Priem, 2011). Kinerja usaha adalah konstruk multidimensi yang mencakup hasil operasional dan keuangan perusahaan (Rizan \& Utama, 2020).

\section{Kaitan antara Kreativitas dengan Kinerja}

Tinggi atau rendahnya suatu Kreativitas akan mempengaruh tinggi rendahnya suatu kinerja. Dengan adanya kreativitas memberikan pengaruh yang signifikan terhadap Kinerja (Arshad, Rasli, Arshad, \& Zain, 2014).

\section{Kaitan antara Pengambilan Resiko dengan Kinerja}

Pengambilan Resiko mempunyai keterkaitan terhadap Kinerja usaha, pengambilan resiko menjadi tantangan oleh pelaku usaha, karena kurangnya kapasitas dan sumber daya yang tepat untuk mendapatkan informasi kualitatif yang akan membantu mengambil keputusan (Agu, Isichei, \& Olabosinde, 2018).

\section{Kaitan antara Orientasi Masa Depan dengan Kinerja}

Dengan menerapkan orientasi masa depan maka akan memberikan pengaruh yang signifikan terhadap kinerja (Simpson \& Radford, 2014).

\section{Kaitan antara Keterbukaan Untuk Berubah dengan Kinerja}

Dengan adanya perubahan yang terjadi maka akan memberikan pengaruh yang signifikan terhadap Kinerja usaha (Miller, Johnson, \& J.Grau, 1994).

\section{Kaitan antara Proaktif dengan Kinerja}

Proaktif menjadi peran penting terhadap kinerja usaha, pelaku usaha yang memiliki sikap proaktif dipercaya dapat bertahan melalui masa-masa gelojak ekonomi yang parah disebabkan oleh krisis ekonomi (Utama \& Nadi, 2017). Proaktif mempunyai kaitan dengan kinerja usaha, selera dan permintaan konsumen yang berubah membutuhkan proaktif yang ekstrim dalam perusahaan (Slater \& Narver, 1995).

Kerangka pemikiran dalam penelitian ini ada sebagai berikut :

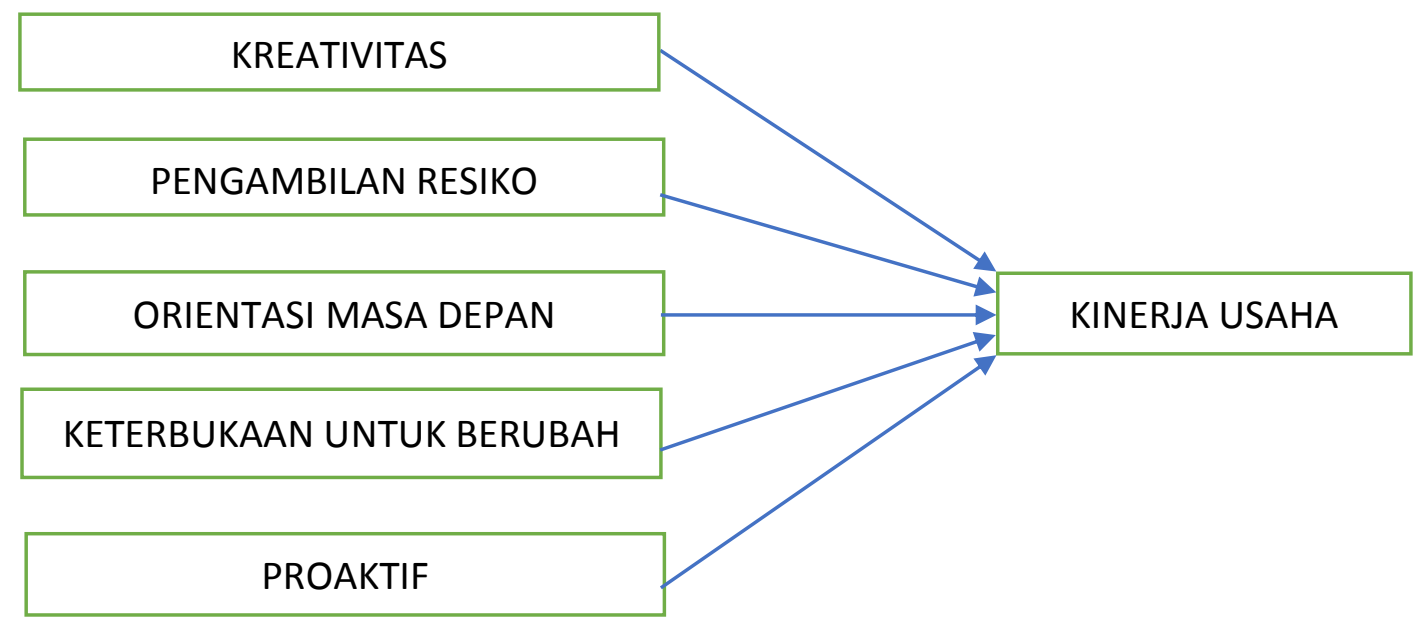


Gambar 1. Kerangka Pemikiran

Hipotesis dari model yang dibangun diatas adalah sebagai berikut :

H1 : Terdapat pengaruh Kreativitas terhadap Kinerja UMKM bidang kuliner di kota Tanjungpinang.

H2 : Terdapat pengaruh Pengambilan Resiko terhadap Kinerja UMKM bidang kuliner di kota Tanjungpinang.

H3 : Terdapat pengaruh Orientasi Masa Depan terhadap Kinerja UMKM bidang kuliner di kota Tanjungpinang.

H4 : Terdapat pengaruh Keterbukaan Untuk Berubah terhadap Kinerja UMKM bidang kuliner di kota Tanjungpinang.

H5 : Terdapat pengaruh Proaktif terhadap Kinerja UMKM bidang kuliner di kota Tanjungpinang.

\section{METODOLOGI}

Penelitian ini menggunakan desain penelitian deskriptif karena tidak ada variabel yang dimanipulasi. Desain yang digunakan dalam penelitian ini yaitu cross-sectional design karena pengumpulan data dari sampel hanya satu kali. Sampel yang digunakan pada penelitian ini yaitu UMKM bidang kuliner di kota Tanjungpinang.

Metode yang digunakan dalam teknik pemilihan sampel penelitian ini menggunakan metode nonprobability sampling. Metode nonprobability sampling adalah teknik sampling yang tidak menggunakan prosedur seleksi peluang sebaliknya mereka bergantung pada penilaian pribadi dari peneliti (Maholtra, 2010). Ukuran sampel untuk PLS-SEM adalah lebih dari 30 responden dan kurang dari 500 responden, dalam penelitian multivariat termasuk analisis regresi berganda maka ukuran sampel yang dibutuhkan minimal harus 10 kali dari variabel yang akan teliti (Roscoe, 1975). Dalam penelitian ini terdapat 6 variabel maka sampel yang diperlukan dalam penelitian ini adalah sebanyak 60 responden.

Pengukuran tanggapan responden akan diukur menggunakan skala Likert. Skala likert akan menunjukan kategori tanggapan dari responden dengan tingkat kesepakatan atas rangkaian pernyataan yang terdapat dalam operasional variabel dan instrument (Maholtra, 2010). Pengukuran tanggapan responden diukur sesuai bobotnya, yaitu Sangat Tidak Setuju (STS) = 1, Tidak Setuju $(T S)=2$, Netral $(N)=3$, Setuju $(S)=4$, Sangat Setuju $(S S)=5$.

\section{HASIL ANALISIS DATA}

Dalam mengukur validitas terdapat 2 model yaitu model convergent validity dan discriminant validity. Convergent validity diukur menggunakan avarage variance extracted (AVE) dan loading factor. Indikator dapat dikatakan valid apabila nilai dari AVE lebih dari 0,5 dan nilai dari loading factor lebih dari 0,7 , namun untuk penelitian tahap awal nilai 0,5 sampai 0,6 masih dianggap cukup. Discriminant validity diukur menggunakan nilai dari cross loading dengan cara membandingkan nilai dari loading factor pada konstruk yang dituju harus lebih besar dari nilai loading factor konstruk lain dan juga menggunakan nilai dari AVE jika lebih dari 0,5 maka dapat dikatakan valid. Seluruh nilai outer loadings pada penelitian ini memiliki nilai diatas 0,5 .

Hasil dari pengujian average variance extracted (AVE) menunjukkan bahwa variabel keterbukaan untuk berubah memiliki nilai AVE tertinggi sebesar 0.628, dan variabel proaktif memiliki nilai AVE terendah sebesar 0.493.

Uji reliabilitas dapat dikatakan reliabel apabila nilai masing-masing indikator dari cronbach alpha lebih dari 0,6 dan composite realibility nya lebih dari 0,7 . Nilai dari cronbach 
alpha pada penelitian ini seluruh konstruk lebih dari 0,6 sehingga dapat dikatakan bahwa konstruk tersebut reliabel. Nilai dari composite realibilty pada penelitian ini seluruh konstruk lebih dari 0,7 sehingga dapat dikatakan bahwa konstruk tersebut reliabel.

Nilai dari hasil Uji $\mathrm{R}^{2}$ digunakan untuk menilai variasi pengaruh antara variabel endogen dan variabel eksogen yang diteliti. Semakin tinggi nilai $\mathrm{R}^{2}$ maka dapat dikatakan bahwa semakin baik pula model penelitian yang dilakukan. Nilai dari $\mathrm{R}^{2}$ dalam penelitian ini adalah 0.979 yang artinya bahwa coefficient of determination $\left(\mathrm{R}^{2}\right)$ memiliki pengaruh yang kuat.

Nilai dari hasil uji cross-validited redudancy $\left(\mathrm{Q}^{2}\right)$ merupakan tahap penilaian predictive relevance dari inner model. Jika nilai $\mathrm{Q}^{2}$ lebih besar dari nol maka model memiliki predictive relevance. Nilai dari $\mathrm{Q}^{2}$ dalam penelitian ini lebih dari nol yaitu sebesar 0.450 yang berarti model memiliki predictive relevance.

Dalam menghitung nilai uji GoF pada penelitian, peneliti harus lebih dulu menghitung atau mengetahui nilai dari AVE dalam penelitian tersebut. Sebelum menghitung nilai dari GoF, peneliti perlu menghitung nilai rata-rata AVE dari variabel-variabel yang ada. Berikut perhitungan yang dilakukan:

$$
\text { Rata-rata Ave }=\frac{0.610+0.440+0.593+0.628+0.493+0.495}{6}=0.543
$$

Kemudian berdasarkan pada tabel 4.12 diketahui bahwa nilai dari coefficient of determination $\left(\mathrm{R}^{2}\right)$ adalah sebesar 0.979 , maka nilai dari GoF sebesar:

Gof $=\sqrt{0.543 \times 0.979}=0.729$

Berdasarkan perhitungan GoF diatas, nilai GoF pada penelitian ini adalah sebesar 0.729 maka dapat dikatakan bahwa model yang digunakan dalam penelitian ini memiliki kecocokan model penelitian yang tergolong besar.

Uji hipotesis digunakan untuk mengetahui hubungan antara variabel-variabel dalam penelitian ini dengan melihat hasil dari boostrapping bagian $\mathrm{T}$ statistic dan $\mathrm{P}$ values. Syarat sebuah hipotesis dalam penelitian tidak di tolak apabila nilai dari T statistic lebih besar dari 1,96 dan nilai dari $\mathrm{P}$ values lebih kecil dari 0,05

Berdasarkan hasil pengujian yang telah dilakukan pada variabel kreativitas terhadap kinerja usaha. Nilai path coefficient yaitu sebesar 0.093 yang menunjukkan bahwa pengaruh antara variabel kreativitas terhadap kinerja adalah searah. Berdasarkan hasil uji hipotesis dapat dikatakan bahwa $\mathrm{H} 1$ tidak ditolak karena variabel kreativitas memiliki nilai $\mathrm{T}$ statistic sebesar 1.986 dan nilai $\mathrm{P}$ values 0.048 . Nilai tersebut telah memenuhi kriteria yang dibutuhkan yaitu nilai T statistic harus lebih besar dari 1,96 dan nilai $\mathrm{P}$ values lebih kecil dari 0,05. Dari penjelasan tersebut, maka dapat dikatakan bahwa variabel kreativitas dapat mempengaruhi kinerja UMKM bidang kuliner.

Berdasarkan hasil pengujian yang telah dilakukan pada variabel pengambilan resiko terhadap kinerja usaha. Nilai path coefficient yaitu sebesar 0.499 yang menunjukkan bahwa pengaruh antara variabel pengambilan resiko terhadap kinerja adalah searah. Berdasarkan hasil uji hipotesis dapat dikatakan bahwa $\mathrm{H} 2$ tidak ditolak karena variabel pengambilan resiko memiliki nilai T statistic sebesar 7.946 dan nilai $\mathrm{P}$ values 0.000 . Nilai tersebut telah memenuhi kriteria yang dibutuhkan yaitu nilai $\mathrm{T}$ statistic harus lebih besar dari 1,96 dan nilai $\mathrm{P}$ values lebih kecil dari 0,05. Dari penjelasan tersebut, maka dapat dikatakan bahwa variabel pengambilan resiko dapat mempengaruhi kinerja UMKM bidang kuliner.

Berdasarkan hasil pengujian yang telah dilakukan pada variabel orientasi masa depan terhadap kinerja usaha. Nilai path coefficient yaitu sebesar 0.655 yang menunjukkan bahwa pengaruh antara variabel orientasi masa depan terhadap kinerja adalah searah. Berdasarkan hasil uji hipotesis dapat dikatakan bahwa H3 tidak ditolak karena variabel orientasi masa depan 
memiliki nilai T statistic sebesar 13.128 dan nilai $\mathrm{P}$ values 0.000 . Nilai tersebut telah memenuhi kriteria yang dibutuhkan yaitu nilai T statistic harus lebih besar dari 1,96 dan nilai $\mathrm{P}$ values lebih kecil dari 0,05. Dari penjelasan tersebut, maka dapat dikatakan bahwa variabel orientasi masa depan dapat mempengaruhi kinerja UMKM bidang kuliner.

Berdasarkan hasil pengujian yang telah dilakukan pada variabel keterbukaan untuk berubah terhadap kinerja usaha. Nilai path coefficient yaitu sebesar -0.099 yang menunjukkan bahwa pengaruh antara variabel keterbukaan untuk berubah terhadap kinerja adalah berlawanan arah, hal ini dikarenakan pada masa pandemi ini mengakibatkan penuruan penjualan, sehingga para pengusaha takut untuk melakukan perubahan karena tetap menjaga modal usaha. Namun berdasarkan hasil uji hipotesis dapat dikatakan bahwa $\mathrm{H} 4$ tidak ditolak karena variabel keterbukaan untuk berubah memiliki nilai T statistic sebesar 2.477 dan nilai $\mathrm{P}$ values 0.014 . Nilai tersebut telah memenuhi kriteria yang dibutuhkan yaitu nilai $\mathrm{T}$ statistic harus lebih besar dari 1,96 dan nilai P values lebih kecil dari 0,05. Dari penjelasan tersebut, maka dapat dikatakan bahwa variabel keterbukaan untuk berubah dapat mempengaruhi kinerja UMKM bidang kuliner.

Berdasarkan hasil pengujian yang telah dilakukan pada variabel proaktif terhadap kinerja usaha. Nilai path coefficient yaitu sebesar -0.103 yang menunjukkan bahwa pengaruh antara variabel proaktif terhadap kinerja adalah berlawanan arah, hal ini dikarenakan pandemi ini mengakibatkan adanya penuruan penjualan yang diakibatkan adanya pembatasan sosial berskala besar (PSBB) yang dilakukan secara mendadak, sehingga para pengusaha tidak memiliki waktu untuk mengantisipasi perubahan yang terjadi. Berdasarkan hasil uji hipotesis maka dapat dikatakan bahwa $\mathrm{H} 5$ ditolak karena variabel proaktif memiliki nilai T statistic sebesar 1.547 dan nilai $\mathrm{P}$ values 0.123 . Nilai tersebut tidak memenuhi kriteria yang dibutuhkan yaitu nilai $\mathrm{T}$ statistic harus lebih besar dari 1,96 dan nilai $\mathrm{P}$ values lebih kecil dari 0,05. Dari penjelasan tersebut, maka dapat dikatakan bahwa variabel pengambilan resiko tidak mempengaruhi kinerja UMKM bidang kuliner.

\section{DISKUSI}

Dari hasil penelitian yang telah dijabarkan diatas membuktikan bahwa dengan adanya kreativitas mempengaruhi kinerja UMKM bidang kuliner. Untuk meningkatkan kinerja UMKM bidang kuliner maka pelaku UMKM harus mempunyai kreativitas yang tinggi. Dengan adanya kreativitas yang dimiliki oleh pelaku usaha, maka pelaku usaha dapat menciptakan suatu produk/jasa yang baru sehingga dapat menarik perhatian pelanggan untuk membeli produk atau menggunakan jasa yang baru, dengan adanya peningkatan pada penjualan maka dapat meningkatkan kinerja usaha.

Dari hasil penelitian yang telah dijabarkan diatas membuktikan bahwa pengambilan resiko mempengaruhi kinerja UMKM bidang kuliner. Untuk meningkatkan kinerja UMKM bidang kuliner maka pelaku UMKM harus berani mengambil resiko. Pelaku usaha yang mengambil resiko dengan benar maka akan memberikan peluang yang besar terhadap kinerja usaha yang dijalankan. Seorang pelaku usaha harus berani dalam mengambil resiko untuk mencapi kinerja yang lebih baik.

Dari hasil penelitian yang telah dijabarkan diatas membuktikan bahwa orientasi masa depan mempengaruhi kinerja UMKM bidang kuliner. Untuk meningkatkan kinerja UMKM bidang kuliner maka pelaku UMKM harus berorientasi masa depan. Dengan adanya orientasi masa depan di suatu usaha, maka seorang pelaku usaha dapat fokus terhadap visi usaha pada masa yang akan datang dan pelaku usaha yang menerapkan orientasi masa depan dipercayai dapat mengungguli pesaing untuk kedepannya, sehingga kedepannya penjualan akan terus meningkat dan kinerja usaha akan menjadi lebih baik. 
Dari hasil penelitian yang telah dijabarkan diatas membuktikan bahwa keterbukaan untuk berubah mempengaruhi kinerja UMKM bidang kuliner. Untuk meningkatkan kinerja UMKM bidang kuliner maka pelaku UMKM harus mempunyai sifat keterbukaan untuk berubah. Dengan menetapkan keterbukaan untuk berubah pada suatu usaha, maka suatu usaha memilik kemampuan untuk beradaptasi dan mencakup kesiapan untuk berubah. Seorang pelaku usaha yang mengadopsi keterbukaan untuk berubah juga selalu mengadopsi inovasi baru, sehingga pelanggan tidak akan bosan dengan usaha yang kita jalankan, dengan adanya penjualan yang terus menerus maka akan meningkatkan kinerja usaha.

Pada penelitian ini mendapatkan hasil bahwa proaktif tidak berpengaruh terhadap kinerja usaha. Untuk meningkatkan kinerja usaha maka seorang pelaku usaha harus mempunyai sifat proaktif, karena seorang yang mempunya sifat proaktif dapat memperoleh perhatian konsumen melalui identifikasi dan pengembangan produk baru di depan konsumen dan pesaing. Tetapi penelitian dilakukan pada masa pandemi ini, dimana perubahan selera dan permintaan konsumen pada masa pandemi ini sangat cepat sehingga pelaku usaha tidak dapat memperoleh perhatian konsumen dan pada masa pandemi ini mengakibatkan penurunan pada penjualan yang sangat banyak, sehingga pelaku usaha tidak berani mengeluarkan modal untuk melakukan pengembangan produk yang baru. Agar proaktif memiliki pengaruh terhadap kinerja UMKM bidang kuliner, maka diperlukannya modal usaha yang lebih, dan menunggu kestabilan perekonomian. Dikarenakan pada pandemi ini kebutuhan pelanggan berubah dengan sangat cepat.

\section{KESIMPULAN}

Berhubungan dengan hasil penelitian yang sudah didapatkan, peneliti ingin memberikan beberapa saran yang diharapkan bermanfaat. Berikut saran-saran dari peneliti :

a. Peneliti menyarankan pelaku UMKM di Indonesia untuk memperhatikan kebutuhan pelanggan agar dapat membuat pelanggan lama tetap membeli produk kita dan mendaopat pelanggan yang baru.

b. Peneliti menyarankan pelaku UMKM di Indonesia untuk tetap menjaga kualitas produk, dapat menciptakan produk yang baru, dan dapat beradaptasi sesuai lingkungan.

c. Untuk peneliti selanjutnya, disarankan untuk dapat melakukan penelitian setelah pandemi Covid-19.

d. Untuk peneliti selanjutnya, disarankan untuk menambah variabel inovasi.

e. Untuk peneliti selanjutnya, disarankan untuk memperluas jangkuan dalam pengambilan sampel dan daerah yang diteliti agar bisa memperkuat dan mendapat hasil yang lebih akurat dibanding penelitian sebelumnya.

\section{DAFTAR PUSTAKA}

Agu, M., Isichei, E., \& Olabosinde, T. (2018). Infrastructural development and growth of micro, small and medium scale enterprises (MSME). Academic Journal of Economic Studies, Vol. 4 No. 4, 71-77.

Amabile, T. (1983). The social-psychology of creativity-a componential conceptualization. Journal of Personality and Social Psychology, Vol. 45 No. 2, 357-376.

Amabile, T. M. (1998). How to Kill Creativity. Harvard Business Review 76 (5), 76-87.

Anberg, C., \& Banas, J. (2000). Predictors and outcomes of openness to change in a reorganizing workplace. Journal of Applied Psychology 85 (1), 132-142. 
Arshad, A., Rasli, A., Arshad, A., \& Zain, Z. (2014). The impact of entrepreneurial orientation on business performance: a study of technology-based SMEs in Malaysia. Social and Behavioral Sciences, Vol. 130, 46-53.

Barringer, B. R., \& Ireland, R. D. (2006). Entrepreneurship: Successfully launching new ventures. . New Jersey: Person Prentice Hall.

Boyd, B. (1991). Strategic planning and financial performance: a meta-analytical review. Journal of Management Studies 27 (4), 353-374.

Colase. (2009). Is the environmental perfomance, enviromental accounting, agency cost impact on company perfomance? International Journal of Contemporary Accounting.

Dita, \& Soelaiman, L. (2021). Pengaruh Pengambilan Resiko, Inovasi, Proaktif, Competitive Aggesiveness, Dan Otonomi Terhadap Kinerja Usaha Konveksi. Jurnal Manajerial dan Kewirausahaan, Volume III No. 1/2021, 186-195.

Erdem, T., \& Swait, J. (1998). Brand equity as a signaling phenomenon. Journal of Consumer Psychology, Vol. 7 No. 2, 1046-1069.

Ergun, S., \& Kuscu, K. (2013). Innovation orientation, market orientation and e-loyalty: evidence from Turkish e-commerce customers. Procedia - Social and Behavioral Sciences, Vol. 99, 509-516.

Giannopoulou, E., \& Gryszkiewicz, L. d.-J. (2014). Creativity for service information: A practice-based perspective. . Managing service quality,24, 23-44.

Hillebrand, B., Kemp, R., \& Nijssen, E. (2011). Customer orientation and future market focus in NSD. Journal of Service Management, 67-84.

Hult, T., Hurley, R., \& Knight, G. (2004). Innovativeness: its antecedents and impact on business performance. Industrial Marketing Management 33, 429-438.

John, K., Litov, L., \& Yeung, B. (2008). Corporate governance and risk-taking. The Journal of Finance, Vol. 63 No. 4, 1679-1728.

Kallmuenzer, A., \& Peters, M. (2018). Entrepreneurial behaviour, firm size and financial performance: the case of rural tourism family firms. Tourism Recreation Research, Vol. 43 No. 1, 2-14.

Karabulut, T. (2015). Effects of innovation strategy on firm performance: a study conducted on manufacturing firms in Turkey. Procedia of Social Behavior Science, Vol. 195 (1), 13381347.

Lumpkin, G., \& Dess, G. (1996). Clarifying the entrepreneurial orientation construct and linking it to performance. Academy of Management Review, Vol. 21 No. 1, 135-172.

Lynn, G., Monroe, J., \& Paulson, A. (1996). Marketing and discontinuous innovation: the probe and learn process. California Management Review 38, 8-37.

Maholtra. (2010). Introduction: Analyzing Accumulated Knowledge and Influencing Future Research. Review of Marketing Research, 13-28.

Miller, V. D., Johnson, R., \& J.Grau. (1994). Antecedents to Willingness to Participate in a Planned Organizational Change. Journal of Applied Communication Research 22, 5980.

Muhyiddin. (2020). Covid-19, New Normal dan Perencanaan Pembangunan di Indonesia. The Indonesian Journal of Development Planning Volume IV No. 2 .

Mwaura, A., Gathenya, J., \& Kihoro, J. (2015). Dynamics of entrepreneurial orientation on the performance of women owned enterprises in Kenya. International Journal of Academic Research in Business and Social Sciences, Vol. 5 No. 9, 222-239.

Nakano, M., \& Nguyen, P. (2012). Board size and corporate risk taking: further evidence from Japan. Corporate Governance an International Review, Vol. 20 No. 4, 369-387.

Ndofor, H., \& Priem, R. (2011). Immigrant entrepreneurs, the ethnic enclave strategy, and venture performance. ournal of Management, Vol. 37 (3), 790-818. 
Nugroho, D. E. (2020, juni 30). survei kinerja UMKM di masa Pandemi Covid-19. Retrieved from Lipi.go.id: http://lipi.go.id/berita/survei-kinerja-umkm-di-masa-pandemicovid19/22071

Rizan, J., \& Utama, L. (2020). Pengaruh Keterampilan Kewirausahaan, Orientasi pasar dan Orientasi Penjualan terhadap Kinerja Usaha UMKM. Jurnal Manajerial Dan Kewirausahaan 2(4), 961-968.

Roscoe, J. T. (1975). Fundamental Research Statistics for the Behavioral Sciences, 2nd ed. New York: Holt, Rinehart and Winston.

Simpson, B., \& Radford, S. (2014). Situational variables and sustainability in multi-attribute decision-making. European Journal of Marketing, Vol. 48, 1046-1069.

Simpson, B., \& Radford, S. (2014). Situational variables and sustainability in multi-attribute decision-making. European Journal of Marketing, Vol. 48 Nos 5/6, 1046-1069.

Slater, S., \& Narver, J. (1995). Market orientation and the learning organization. Journal of Marketing, Vol. 59, 63-74.

Utama, L., \& Nadi, J. K. (2017). Pengaruh Kreativitas terhadap Kinerja Usaha dengan orientasi kewirausahaan sebagai mediasi pada wirausaha di ITC Cempaka Mas. Conference on Managerial and Behavorial Studies, 80-88.

Wanberg, C., \& Banas, J. (2000). Predictors and outcomes of openness to change in a reorganizing workplace. Journal of Applied Psychology 85 (1), 132-142.

Werlang, N., \& Rossetto, C. (2019). The effects of organizational learning and innovativeness on organizational performance in the service provision sector. Gestao and Producao, Vol. $26(3)$.

Wiklund, J. d. (2005). Entrepreneurial Orientation and Small Business Performance: A Configurational Approach. Journal of Business Venturing 20(1), 71-91.

Willison, \& Rodhiah. (2021). Pengaruh Creativity, Proactive Personality, Dan Entrepreneurial Alertness Terhadap Itensi Berwirausaha Pada Mahasiswa. Jurnal Manajerial dan Kewirausahaan, Volume III No. 2/2021 , 548-558.

Zainal, M. (2020). Innovation orientation and performance of Kuwaiti family businesses: evidence from the initial period of COVID-19 pandemic. Journal of Family Business Management. 